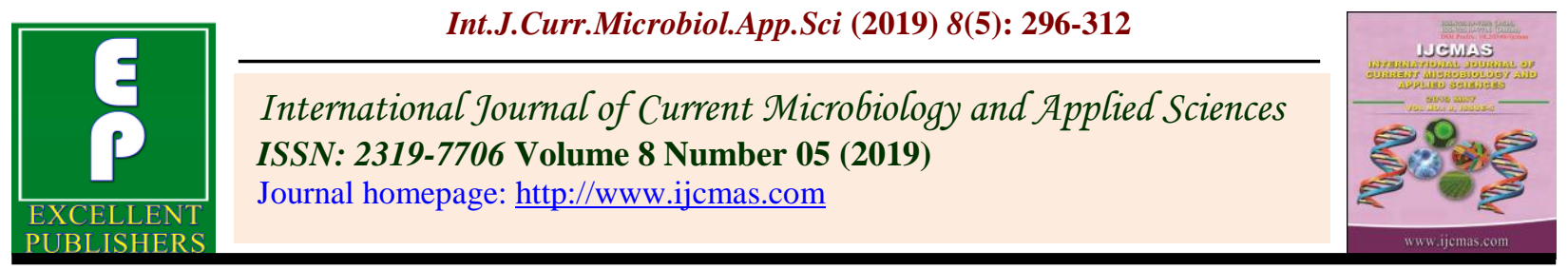

\title{
Screening and Isolation of Lipase Producing Bacteria from Contaminated Soils from the Littoral-Region of Cameroon and Partial Study of the Fermentation Conditions of the Crude Enzyme Produced
}

\author{
Fobasso Tagnikeu Romeo ${ }^{1}$, Tavea Fréderic Marie $^{1 *}$, Tetso Ghislain Brice ${ }^{3}$, \\ Tchamba Mbiada Mervie Noel ${ }^{4}$, Tcheugoue Styve Joel ${ }^{1}$, Momo Gautier ${ }^{1}$ and \\ Etoa François Xavier ${ }^{2}$
}

\author{
${ }^{1}$ Department of Biochemistry, Faculty of Science, University of Douala, Cameroon \\ ${ }^{2}$ Department of Biochemistry, Faculty of Science, University of Yaoundé I, Cameroon \\ ${ }^{3}$ Department of Biochemistry, Faculty of Science, University of Buea, Cameroon \\ ${ }^{4}$ Department of Food Sciences and Nutrition, ENSAI Ngaoundéré, Cameroon
}

*Corresponding author

\begin{tabular}{|l|}
\hline Ke y w or d s \\
Thermostable \\
lipase, Isolation, \\
Littoral-Cameroon, \\
Fermentation, \\
Bacillus
\end{tabular}

A B S T R A C T

Lipases are enzymes that catalyze the transformation reactions of triglycerides in to fatty acids and glycerol. They can be produced by animals, plants and microorganisms. This article presents the isolation of lipase-producing bacteria from soil samples collected from sites contaminated with waste from palm oil production in the littoral region of Cameroon. These permit to isolate a multitude of bacteria capable of producing lipase from Rhodamine B-agar olive oil culture medium. Of the 35 isolates obtained from the 66 soil samples, one was selected as the best based on its enzymatic activity, the $\mathrm{DI}_{1} \mathrm{~A}$ isolate. After production of the crude enzyme, the influence of temperature and $\mathrm{pH}$ on it was studied, followed by the impact of some physicochemical parameters on the fermentation medium. The $\mathrm{DI}_{1} \mathrm{~A}$ isolate produced a crude enzyme showing better activity of $5.63 \pm 0.31$ $\mathrm{IU} / \mathrm{ml}$ with optimal activity at a temperature of $55^{\circ} \mathrm{C}$ and a $\mathrm{pH}$ of 8 . The study of the influence of some physico-chemical parameters on the isolate showed an optimal growth temperature at $38^{\circ} \mathrm{C}$, an optimum $\mathrm{pH}$ at 7 , the best carbon source is palm kernel oil at $1 \%$ $(\mathrm{v} / \mathrm{v})$, the best nitrogen source is ammonium chloride at $2 \%(\mathrm{~m} / \mathrm{v})$ and the best salt source is magnesium sulphate at $3 \%(\mathrm{~m} / \mathrm{v})$. Macroscopic and microscopic analyses reveal that the $\mathrm{DI}_{1} \mathrm{~A}$ isolate is a Gram+ bacillus, a positive catalase capable of sporulating.

\section{Introduction}

Enzymes have been used since ancient civilizations. Nowadays, more than 4000 enzymes are known and about 200 are used for commercial purposes, most of them fungal and bacterial (Sharma et al., 2001). Until the 1960s, the enzyme market was worth only a few million dollars a year, but since then the market has evolved dramatically (Wilke, 1999). The market for industrial enzymes is growing rapidly, because of the emergence of 
new fields of application. In 2007, the global market for industrial enzymes was estimated at \$2.3 Billions while lipases accounted for only $5 \%$ of the total market (Jyoti and Avneet 2006). This rate can increase significantly through a range of application areas. Thus, the growing demand for enzymes of particularly bacterial origin owes its applications to several production fields: Food processing industries, pharmaceutical industries, chemical industries and textile industries (Patil et al., 2011). In addition to lipolytic properties, lipases have esterification properties (Jaeger and Ritz, 1998).

The growing importance of lipases in biotechnological perspectives can easily be seen in the number of journals and articles that cover the variable aspects of this highly versatile enzyme: Biochemistry, Molecular Biology, Purification Approach and Biotechnology Applications (Gupta et al., 2004). Lipases are enzymes produced by many plants, animals and microorganisms. The most exploited bacteria lipases are: Archomobacter, Alicagens, Arthrobacter, Baccillusburkhoderia, Chromobacterium and Pseudomonas sp. (Gupta et al., 2004).

Despite the considerable progress made in recent years in the production of bacterial lipase, the isolation of this type of microorganism remains a major challenge. For this reason, scientists must move to isolate microorganisms capable of producing lipases in order to increase the number of bacteria available. The objective of this work is to isolate a thermostable lipase producing bacterium.

\section{Materials and Methods}

\section{Isolation}

The liquid fermentation medium consists of: $0.2 \% \quad(\mathrm{~m} / \mathrm{v})$ yeast extract; $0.5 \% \quad(\mathrm{~m} / \mathrm{v})$ peptone; $0.02 \%(\mathrm{~m} / \mathrm{v}) \mathrm{MgSO}_{4} ; 0.3 \% \mathrm{NaCl}$; $0.1 \%(\mathrm{~m} / \mathrm{v}) \quad \mathrm{KH}_{2} \mathrm{PO}_{4} ; 0.5 \%$ (v/v) olive oil; $0.05 \%$ (v/v) tween 80 as emulsifier. The whole was dissolved in distilled water and the $\mathrm{pH}$ of the medium adjusted to 8 by adding $0.3 \%(\mathrm{~m} / \mathrm{v}) \mathrm{Na}_{2} \mathrm{CO}_{3}$ and then distributed to the Erlenmeyer. Each Erlenmeyer contains $1 / 10$ of its volume in a liquid medium. This medium was autoclaved at $121^{\circ} \mathrm{C}$ for 20 minutes. After cooling, 5 grams of soil sample taken from palm oil waste dumps were introduced and incubated under agitation in a water bath at $37{ }^{\circ} \mathrm{C}$ for 24 hours.

The solid isolation medium has the same composition as the liquid fermentation medium in the presence of Rhodamine B and agar. This enrichment medium was diluted decimal, then 5 microlitres of each fraction were spread on the surface on the AgarRhodamine B medium contained in the petri dishes according to the method used by Bhavani et al., in 2012, then incubated in an oven at $37^{\circ} \mathrm{C}$ for 24 hours.

The lipolytic capacity of a colony has been materialized by the presence of a fluorescent halo around it. The isolate with a larger diameter halo and a small colony was retained and maintained on inclined agar.

\section{Production of the crude enzyme}

It was carried out using fermentation in a liquid medium (Hupé, 2008). Indeed, 10ml of a fermentation medium previously autoclaved at $121^{\circ} \mathrm{C}$ for 20 minutes are distributed in 50 $\mathrm{ml}$ Erlenmeyer.

After cooling, a suspension of bacterial colonies was introduced. The Erlenmeyer are incubated under oscillation in a water bath at $30^{\circ} \mathrm{C}$ for 24 hours. After fermentation, the various media are centrifuged. The recovered supernatant is considered to be the crude enzyme. It is stored at $+4^{\circ} \mathrm{C}$ for further work. 


\section{Screening of the best isolate}

\section{Evaluation of the relative activity}

\section{Halodiameters measuring method}

Relative activity is the distance of diffusion of the enzyme through the gel. It consisted in measuring the diameters of the colonies (Dc) and those of the haloes (Dh) using a graduated ruler and making the ratio $\mathrm{Da} / \mathrm{Dh}$. Hydrolytic activity was based on this ratio. The colonies with the highest ratios were selected for the evaluation of enzyme activity.

\section{Well method}

$60 \mu \mathrm{L}$ of the crude enzyme obtained is introduced into the wells and incubated at $37^{\circ} \mathrm{C}$ for 48 hours. Opaque haloes around the wells are observed, demonstrating that these enzymes are capable of hydrolyzing lipids. The diameter of each halo is based on the lipase activity. The larger it is, the higher the activity.

\section{Evaluation of enzymatic activity}

The enzymatic activity of the pre-selected isolates was determined by the titration method described by Sharma et al (2012) with slight modifications in the incubation time. Lipolytic activity is determined in an emulsified system using olive oil as substrate and tween 80 as emulsifier. The substrate must be properly emulsified because the lipolytic activity varies directly with the surface of the substrate available for the enzyme. Vigorous agitation of the emulsion is acceptable (Sharma et al., 2012).

Study of the influence of some physicochemical parameters

Factors affecting the growth of microorganisms such as fermentation time, $\mathrm{pH}$, temperature, sources and quantities of substrate (lipids), as well as sources and quantities of nitrogen and mineral salts affecting lipase production are partially studied by varying experimental conditions. The experiments are carried out in $50 \mathrm{ml}$ Erlenmeyers flask containing $10 \mathrm{ml}$ of liquid medium by varying the parameters to be studied. The $\mathrm{pH}$ is maintained at 7.5 and the temperature at $37^{\circ} \mathrm{C}$.

\section{Results and Discussion}

\section{Isolation}

Lipolytic strains are those with haloes (light areas around the colony) (photograph 1).

There is a predominance of isolates in Pool No. 2 and an absence in Pool No. 3 and the YATO site. In Pool No. 1 and the Souza site, only a few bacteria are observed. Yato site, only 2 years old, its microorganisms would not yet be suitable for the production of fatty acid hydrolases (lipases). Pool No. 3, devoid of any form of fat, cannot also serve as a biotope for these microorganisms. The remaining sites, which are older and content requirements of fat, are the ideal biotopes for these microorganisms (Table 1).

\section{Screening of the best isolate}

Evaluation of the relative activity and partial identification of the best isolate

\section{Halodiameters measuring method}

In order to determine the hydrolytic activity $(\mathrm{R}=\mathrm{Da} / \mathrm{Dh})$ of lipases excreted by the colonies, the diameters of the colonies (Dc) and halos (Dh) were measured after 48 hours of incubation at $37^{\circ} \mathrm{C}$. The screening of lipolytic strains was made possible by the value of this activity $(\mathrm{R}=\mathrm{Dc} / \mathrm{Dh})$. The screening technique highlights the microorganisms that produce lipolytic 
enzymes. It can be seen that the microorganisms in Pool $\mathrm{N}^{\circ} 2$ have the highest activities while the other sites have microorganisms with relatively lower activities (Table 2). This could be explained by the saturation of the Souza site and the Pool No. 1 with fat, as the Pool No. 2 has a very low oil content

\section{Well method}

Knowing that microorganisms have the lipolytic capacity, this manipulation aims to evaluate the activity of the crude enzyme produced.

All the isolates obtained showed lipase activity through the appearance of haloes around the wells (Photograph 2). Statistical analyses show that relative activity varies significantly between isolates $(H=21.206$; $p$ 0.0001).

Figure 1 below shows that some isolates have a better relative activity compared to others. These are mainly isolates from the lagoon and mainly from pools $\mathrm{N}^{\circ} 1$ and $\mathrm{N}^{\circ} 2$. This may be due to their age and the presence of fat in the environment.

\section{Determination of the activity of the best pre-selected isolates}

Titrimetry was performed as described by sharma et al., in 2012. The purpose of this activity is to select the best isolate.

Although these isolates showed good activity compared to some strains already studied, statistical analyses of the data showed a significant variation in activity with each isolate $(H=20,500 ; p=0.0046)$. Figure 2 shows that the enzyme produced by DI1A has the highest activity at $5.63 \pm 0.31$. This activity is significantly higher than that obtained by Aspergillus niger $1.5(\mathrm{IU} / \mathrm{ml})$ by Sharma et al,
(2001) and Bacillus safensis (0.248 IU/ml); Bacillus megaterum $(0.203 \mathrm{IU} / \mathrm{ml})$ by Khataminezhad et al., (2014) who used the titrimetric method.

\section{Partial identification of $\mathrm{DI}_{1} \mathrm{~A}$}

Macroscopic, microscopic examinations and biochemical tests are performed for the partial identification of $\mathrm{DI}_{1} \mathrm{~A}$ (Table 3).

The DI1A isolate is whitish, producing a green pigmentation. It is capable of growing at $55^{\circ} \mathrm{C}$, the edge of its colonies are regular, semi-bomled with a shiny and creamy surface, positive catalase. Under a microscope, $\mathrm{DI}_{1} \mathrm{~A}$ is a Gram+ bacillus capable of sporulating (Table 3). Khataminezhad et al., (2014) showed through studies on Bacillus safensis and Bacillus megaterumthat several bacteria producing lipolytic enzymes were generally Gram-positive, catalasepositive, sporulated, aerobic bacilli; characteristics common to the majority of Bacillus species (Seeley and VanDemark, 1981; Fergus, 2008).

Study of the influence of some physicochemical parameters on the production of DI $_{1}$ Alipases.

\section{Influence of temperature on enzymatic production}

Microorganisms are deeply affected by the temperature of their environment since it significantly influences the growth of these microorganisms and therefore the production of enzymes (Figure 3).

The influence of temperature variations $(25$, $30,37,40,45,55$ and $60^{\circ} \mathrm{C}$ ) is studied at $\mathrm{pH}$ 8 , at $107 \mathrm{rpm}$ and in the presence of olive oil $(0.5 \%)$ as a carbon source. Statistical analyses of the data show thatenzymatic activity varies 
significantly with temperature $(\mathrm{H}=18.130$; $\mathrm{p}=0.0059$ ).

Figure 3 shows a peak at $38^{\circ} \mathrm{C}(5.30 \pm 0.39$ IU/ml): This is the optimal temperature. This activity drops lightly between 40 and $45^{\circ} \mathrm{C}$ and then drops sharply above $55^{\circ} \mathrm{C}$. Each microorganism has an optimal temperature at which maximum enzyme production occurs. In ourstudy, the optimal temperature for enzyme production is $38^{\circ} \mathrm{C}$. Meenakshi and Hindumathy (2014) reported maximum enzyme production at $37^{\circ} \mathrm{C}$ by odoratiminusmyroids. The optimum production at $38^{\circ} \mathrm{C}$ would have originated from the opening and increase in the permeability of the bacterial membrane, which would have triggered the proper functioning of the body's enzymatic synthesis machinery. The decrease in production above $45^{\circ} \mathrm{C}$ would come from the decrease in cell growth due to the increase in temperature.

\section{Influence of initial pH on enzymatic production}

The initial $\mathrm{pH}$ of the medium playsa key rule in bacterial growth. The influence of the initial $\mathrm{pH}(5,6,7,7,8,9)$ is studied at $30^{\circ} \mathrm{C}$, at $107 \mathrm{rpm}$ and in the presence of olive oil $(0.5 \%)$ as a carbon source. The variation in activity according to $\mathrm{pH}$ is significant $(\mathrm{H}=$ $11.525 ; \mathrm{p}=0.0213$ ).

Figure 4 shows a gradual increase in activity from $\mathrm{pH} 5$ onwards, with a maximum at $\mathrm{pH} 7$ for an activity of $3.89 \pm 0.33 \mathrm{IU} / \mathrm{ml}$. Abovethis $\mathrm{pH}$, there is a gradual decrease in activity between $\mathrm{pH} 8$ and $\mathrm{pH}$ 9. These results are similar to those reported by Huda (2013) in Actinobacter baumannii. However, maximum production at $\mathrm{pH} 9$ has been reported in Bacillus safensis and Bacillus megaterum by Khataminezhad et al., (2014). This suggests that $\mathrm{DI}_{1} \mathrm{~A}$ isalkaline.

\section{Influence of shaking speed on enzymatic production}

The study of the influence of the shaking speed $(90,107,124,124,140$ and $155 \mathrm{rpm})$ was carried out at $30^{\circ} \mathrm{C}, \mathrm{pH} 8$, and in the presence of olive oil $(0.5 \%)$. Production does not vary significantly with agitation rate $(\mathrm{H}=8.775 ; \mathrm{p}=0.0670)$.

At $140 \mathrm{rpm}$, an enzymatic activity of $4.22 \pm$ $0.48 \mathrm{IU} / \mathrm{ml}$ is obtained, which is the optimal shaking speed. Above $140 \mathrm{rpm}$, this activity decreases considerably when reaching 155 rpm (3.96 $\pm 0.64 \mathrm{IU} / \mathrm{ml})$ (Figure 5).

The literature reports that bacterial cultures in agitated environments cause morphological changes, including changes in cell permeability (Darah et al., 2013). Shaking is required for aerobicbacteria to produce lipase since there is virtually no production of lipase in the stationary state (without shaking) (Veerapagouetal., 2013). From the results obtained, it is observed that shaking at $90 \mathrm{rpm}$ increases lipase production. The optimal shaking speed for the production of lipase by $\mathrm{DI}_{1} \mathrm{~A}$ is $140 \mathrm{rpm}$. Beyond this speed, production falls (Figure 5). Lipase production could be increased by increasing the oxygen transfer rate, contact area and good dispersion of the substrate (oil) in the culture medium during fermentation under agitation However, at high shaking speeds, enzyme production decreases. Veerapagou et al., (2013) also reported that lipase production is optimal at $160 \mathrm{rpm}$ and decreases when the agitation rate is increased. This could be due to the fact that high agitation makes the substrate less available. Darah et al., (2011) report that high agitation rates contribute to low enzyme production leading to shear forces, resulting in high cell destruction rates and consequently lower enzyme production. The damage created by these shear forces cannot be 
repaired by excess oxygen in the environment.

Influence of fermentation time on enzymatic production

The fermentation time is decisive for the enzymatic production. The influence of fermentation time on enzyme production is studied at different times $(1 ; 6 ; 12 ; 24 ; 36 ; 48$, 72,90 and 120 hours), at $\mathrm{pH} 8,30^{\circ} \mathrm{C}, 107$ rpm and with olive oil $(0.5 \%)$ as substrate. This production varies significantly over time $(\mathrm{H}=16.251 ; \mathrm{p}=0.0125)$ according to statistical analyses.

After 1 hour of fermentation, there is an increase in enzymatic activity $(1.56 \pm 022$ $\mathrm{IU} / \mathrm{ml})$. This activity varies little between 6 and 12 hours and then increases sharply to $3.41 \pm 0.56 \mathrm{IU} / \mathrm{ml}$ (maximum activity) after 48 hours of fermentation. It tends to decrease after 72 hours $(3.22 \pm 0.51 \mathrm{IU} / \mathrm{ml})$. At 120 hours, there is a considerable decrease of the activity (Figure 6). These results are similar to those reported by Leonov (2010) who worked on Pseudomonas fluorescens and obtained an optimal production time of 48 hours of fermentation, Meenakshiand Hindumathy (2014) who worked on Myroïdesodoratiminus and Abdollahi et al., (2014) on Pseuddomonas sp. An increase in fermentation time leads to a reduction in enzymatic production, this could be due to the exhaustion of nutrients in the medium (Sourav et al, 2011) or probably to the production of secondary metabolites, inhibitors of protein synthesis (Chibuogwu et al., 2009).

\section{Influence of the substrate (carbon source) on enzymatic production}

Peanut, olive, refined (R) and crude palm (R), palm kernel and cocoaoils are used as a substrate (carbon source) at $0.5 \%, \mathrm{pH} 8,30^{\circ} \mathrm{C}$ and $107 \mathrm{rpm}$ to determine their influence on enzyme production. This enzymatic production varies significantly depending on the carbon source used $(\mathrm{H}=15.971 ; \mathrm{p}=$ 0.0069) (Figure 7).

The activity of the enzyme produced from palm kernel oil as the only carbon source $(8.22 \pm 1.79 \mathrm{IU} / \mathrm{ml})$ is higher than that of the enzyme produced from crude palm oil $(6,67 \pm 1.47 \mathrm{IU} / \mathrm{ml})$, olive $(5.07 \pm 1.70 \mathrm{IU} / \mathrm{ml})$, groundnut $(4.15 \pm 0.96 \mathrm{IU} / \mathrm{ml})$, refined palm (R) $(2.52 \pm 0.34 \mathrm{IU} / \mathrm{ml})$ and cocoa $(2.26 \pm 0.93$ IU/ml). (Figure 7). (Savitha et al., 2007) and Meenakshi and Hindumathy (2014).

\section{Influence of substrate concentration} (carbon source) on enzyme production

The influence of palm kerneloil concentration on production was studied $(0.5 ; 1 ; 1 ; 2 ; 2 ; 3 ; 4$ and $5 \%$ ) at $30^{\circ} \mathrm{C}, \mathrm{pH} 8$ and $107 \mathrm{rpm}$.

The activity of the enzyme produced at $1 \%$ is $3.19 \pm 0.34 \mathrm{UI} / \mathrm{ml}$ (maximum activity) significantly higher than that of enzymes produced at other concentrations. It ranges from $2.26 \pm 0.28 \mathrm{IU} / \mathrm{ml}$, at $1 \%$, a gradual decrease in the curve reaches the maximum at $1 \%$, decreases and remains around $1.26 \pm 0.74$ $\mathrm{IU} / \mathrm{ml}$ at $5 \%$ (Figure 8). The amount of substrate is a determining factor in enzyme production because the amount of substrate available conditions the growth of microorganisms. These results can be extrapolated to those of Savitha et al., (2007) and Meenakshi and Hindumathy (2014) who all reported that coconut oil with a composition very close to that of palm kernel oil was the best substrate at $1 \%$ for some fungal isolates and Odoratiminus myroids respectively.

Based on these results, it can be said that the production of enzymes is inductive because the enzyme activity is conditioned by the substrate in presence. 
Influence of the nitrogen source on enzymatic production

Soybean meal (Glycine hispida), beanmeal (Phaseolus vulgaris L.), ammonium sulphate $\left(\left(\mathrm{NH}_{4}\right)_{2} \mathrm{SO}_{4}\right)$, ammonium chloride $\left(\mathrm{NH}_{4} \mathrm{Cl}\right)$, peptone, yeast extract and urea are used as sources of nitrogen at $2 \%, \mathrm{pH} 8,30^{\circ} \mathrm{C}$ and $107 \mathrm{rpm}$ to determine their influence on enzymatic activity. The variation was not significant $(\mathrm{H}=9.887 ; \mathrm{p}=0.1295)$. The activity of the enzyme produced from yeast extract as a source of nitrogen $(8.15 \pm 1.95$ $\mathrm{IU} / \mathrm{ml}$ ) is higher than that of enzymes produced from ammonium chloride $(\mathrm{NH} 4 \mathrm{Cl})$ $(7.96 \pm 3.06 \mathrm{IU} / \mathrm{ml})$, urea $(4.63 \pm 1.16 \mathrm{IU} / \mathrm{ml})$, ammonium sulphate $((\mathrm{NH} \quad 3) 2 \mathrm{SO} 4)$ $(3.52 \pm 1.40 \quad \mathrm{IU} / \mathrm{ml})$, peptone $(3.33 \pm 1.92$ $\mathrm{IU} / \mathrm{ml}$ ), soybean meal (Glycine hispida) $(2.04 \pm 0.85 \mathrm{IU} / \mathrm{ml})$ and beans flour (Phaseolus vulgarisL.) $(1.48 \pm 1.16 \mathrm{IU} / \mathrm{ml})$ (Figure 9). This would be due to the fact that ammonium chloride has nitrogen directly available for the bacteria and the yeast extract would be very rich in available amino acids which can be quickly used for metabolic needs while the others require additional efforts. Ammonium chloride is chosen because yeast extract is more expensive on the market. These results are similar to those obtained by Veerapagou et al., in 2013, where he demonstrated in a study on lipase-producing bacteria that yeast extract was the best organic source while ammonium chloride was the best inorganic source for lipase-producing bacteria

\section{Influence of ammonium chloride concentration (nitrogen source) on enzymatic production}

The influence of ammonium chloride concentration $(0.5 ; 1 ; 1 ; 2 ; 3 ; 4$ and $5 \%)$ at $30^{\circ} \mathrm{C}, \mathrm{pH} 8$ and $107 \mathrm{rpm}$ was investigated.

The activity of the crude enzyme produced increases between $0.5(0.3 \pm 0.23 \mathrm{IU} / \mathrm{ml})$ and
$1 \%(2.07 \pm 0.28 \mathrm{IU} / \mathrm{ml})$, until it reaches its maximum at $2 \%(2.70 \pm 0.28 \mathrm{IU} / \mathrm{ml})$. Above $2 \%$, it gradually decreases to $0.89 \pm 0.22$ $\mathrm{IU} / \mathrm{ml}$ at $5 \%$. (Figure 10). The low activity between 0.5 and $1 \%$ is due to the lack of sufficient elements for metabolism. The decrease at a certain concentration is due to the saturation of the medium with organic elements, including bacterial poisoning.

\section{Influence of mineral salts on enzymatic production}

Mineral salts are essential in enzymatic activity. Some inhibit it while others increase it. At the cellular level, they facilitate the diffusion of nutrients through the membrane. We studied the influence of some salts, namely $\mathrm{NaCl} ; \quad\left(\mathrm{NH}_{4}\right)_{2} \mathrm{SO}_{4} ; \quad \mathrm{KH}_{2} \mathrm{PO}_{4}$; $\mathrm{NaH}_{2} \mathrm{PO}_{4} ; \mathrm{CaCl}_{3} ; \mathrm{FeSO}_{4}$ andMgSO 4

These mineral salts all appear to be suitable for enzyme production but statistical analyses show a significant degree of difference $(\mathrm{H}=15.602 ; \mathrm{p}=0.0081)$ between the salts tested. However, iron sulphate $\left(\mathrm{FeSO}_{4}\right)$ appears to be the least suitable while magnesium sulphate $\left(\mathrm{MgSO}_{4}\right)$ shows better activity (Figure 11). Magnesium ions are cofactors that are sometimes essential for the functioning of certain lipases. Janssen et al., 1994 also report that lipase production by a thermophilic Bacillus was optimal when magnesium, iron, and calcium ions were added to the production medium. Similarly, Pokorny et al., reported in 1994 that $A$. Niger's lipase production was increased in the presence of magnesium.

\section{Influence of $\mathrm{MgSO}_{4}$ concentration on enzyme production}

The influence of magnesium sulphate salt concentration $(0.5 ; 1 ; 1 ; 2 ; 2 ; 3 ; 4$ and $5 \%)$ was studied at $30^{\circ} \mathrm{C}, \mathrm{pH} 8$ and $107 \mathrm{rpm}$. Enzyme production varies significantly with 
salt concentration $(H=13.094 ; \mathrm{p}=0.0225)$. The concentration of salts is very important for enzymatic production. It ranges from $0.70 \pm 0.23 \mathrm{IU} / \mathrm{ml}$ to $0.5 \%$, reaches $2.04 \pm 0.39$ $\mathrm{IU} / \mathrm{ml}$ at $3 \%$ (optimal concentration) and drops sharply to $0.56 \pm 0.22 \mathrm{IU} / \mathrm{ml}$ at $5 \%$ due to saturation effects. (Figure 12). The production of extracellular lipase by Acinobacter calcoaceticus BD 413 was increased when the medium was supplemented with magnesium, (Kok et al., 1995). Sharon et al., (1998) report that the maximum lipase production by $P$. pseudoalcaligenesKka-5 occurred at $0.8 \mathrm{M}$ magnesium; however, the exclusion of magnesium ions from the medium caused an approximately $50 \%$ reduction in lipase production, but supplementing the medium with calcium ions did not affect lipase production. This implies that magnesium ions would be essential for enzymatic production in some microorganisms.

Influence of temperature and $\mathrm{pH}$ on enzymatic activity of the crude enzyme

\section{Influence of temperature on enzymatic activity}

The influence of temperature on enzymatic activity is significant $(\mathrm{H}=13,429 ; \mathrm{p}=0,0367)$. It was determined at different temperatures $\left(20,30,37,40,45,55,60,70\right.$ and $\left.80^{\circ} \mathrm{C}\right)$. The enzymatic activity is equal to $0.81 \pm$ $0.42 \mathrm{UI} / \mathrm{ml}$ at $20^{\circ} \mathrm{C}$. This value gradually increases to a peak corresponding to $3.37 \pm$ $0.45 \mathrm{IU} / \mathrm{ml}$ at $55^{\circ} \mathrm{C}$ and then drops slightly to $3.22 \pm 0.62 \mathrm{IU} / \mathrm{ml}$ at $60^{\circ} \mathrm{C}$. (Figure 13). These results are similar to those reported by Abdollahi et al., (2014) who recorded maximum enzymatic activity at $60^{\circ} \mathrm{C}$ and a sharp decrease from $65^{\circ} \mathrm{C}$ in lipases isolated from Pseuddomonas sp. and those obtained by Qing et al., (2014) who observed maximum enzymatic activity at $60^{\circ} \mathrm{C}$ in lipase isolated from a metagenomic strain.

\section{Influence of pH on enzymatic activity of the crude enzyme}

The influence of $\mathrm{pH}$ variations $(5,6,7,7,8$, 9 ) is studied on the crude enzyme at $30^{\circ} \mathrm{C}$. Analyses show that $\mathrm{pH}$ significantly influences enzymatic activity $(\mathrm{H}=12.308 ; \mathrm{p}=$ $0.0152)$. Figure shows 14 an increase in activity from $\mathrm{pH} 5(0.85 \pm 0.50 \mathrm{IU} / \mathrm{ml})$ to its maximum at $\mathrm{pH} 7(3.89 \pm 0.33 \mathrm{IU} / \mathrm{ml})$ which is maintained at $\mathrm{pH} 8$, above which there is a decrease in activity. At acidic $\mathrm{pH}$, enzyme activity gradually decreased. The lipase produced hydrolyzed the substrate over a relatively short $\mathrm{pH}$ range of 7 to 8 giving an activity of $4.81 \pm 0.36 \mathrm{IU} / \mathrm{ml}$ (Figure 14). these results are similar to those obtained by Shakila et al., (2012) where a study on Serratiamarcescens MBB05 lipase showed maximum activity at $\mathrm{pH} 7$. The enzyme of $\mathrm{DI}_{1} \mathrm{~A}$ is therefore alkaline.

Table.1 Distribution of isolates obtained according to sampling sites

\begin{tabular}{|c|c|c|c|}
\hline \multicolumn{2}{|c|}{ Sampling site } & $\begin{array}{c}\text { Number of } \\
\text { samples }\end{array}$ & $\begin{array}{c}\text { Number of } \\
\text { isolates }\end{array}$ \\
\hline \multicolumn{2}{|c|}{ YAT } & 12 & 0 \\
\hline \multicolumn{2}{|c|}{ SOU } & 22 & 5 \\
\hline & Pool $N^{\circ} 1$ & 12 & 5 \\
\hline \multirow{2}{*}{$\begin{array}{c}\text { DIZANG } \\
\text { UE }\end{array}$} & Pool $N^{\circ} 2$ & 15 & 25 \\
\hline & Pool N³ & 5 & 0 \\
\hline Totals & & 66 & 35 \\
\hline
\end{tabular}


Int.J.Curr.Microbiol.App.Sci (2019) 8(5): 296-312

Table. 2 Hydrolytic activity of isolates

\begin{tabular}{|c|c|c|c|c|}
\hline Sites & $\begin{array}{c}\text { Summer } \\
\text { camps }\end{array}$ & $\begin{array}{c}\text { Diameter of } \\
\text { the halo (48 } \\
\text { hours): Da } \\
(\mathbf{m m})\end{array}$ & $\begin{array}{l}\text { Diameter of } \\
\text { the Colony } \\
\text { (48 hours): } \\
\text { Dc }(\mathrm{mm})\end{array}$ & $\begin{array}{c}\text { Report } \\
\text { R=Da } / \mathrm{Dh}\end{array}$ \\
\hline \multirow{7}{*}{ SOUZA } & $F_{1}$ & 35 & 10 & 3,5 \\
\hline & $F_{2}$ & 20 & 10 & 2 \\
\hline & $\mathbf{F}_{\mathbf{3}}$ & 20 & 10 & 2 \\
\hline & $\mathbf{F}_{4}$ & 20 & 9 & 2,22 \\
\hline & $F_{5}$ & 17 & 8 & 2,12 \\
\hline & $\mathbf{D B}_{1}$ & 20 & 10 & 2 \\
\hline & $\mathbf{D B}_{1}$ & 21 & 12 & 1,75 \\
\hline \multirow[t]{10}{*}{ (Pool No. } & $\mathrm{DI}_{1}$ & 40 & 10 & 4 \\
\hline & $\mathrm{DI}_{1}$ & 26 & 12 & 2,16 \\
\hline & $\mathrm{DI}_{1}$ & 30 & 7 & 3,66 \\
\hline & $\mathrm{DF}_{2} \mathbf{C}$ & 50 & 6 & 8,33 \\
\hline & $\mathrm{DI}_{2} \mathrm{C}$ & 75 & 7 & 10,7 \\
\hline & $\mathrm{DI}_{2} \mathrm{D}$ & 65 & 5 & 13 \\
\hline & $\mathrm{DD}_{2} \mathbf{D}$ & 23 & 8 & 2,87 \\
\hline & $\mathrm{DD}_{\mathbf{2}} \mathrm{C}$ & 18 & 5 & 3,6 \\
\hline & $\mathrm{DF}_{2} \mathbf{A}$ & 29 & 7 & 4,14 \\
\hline & $\mathrm{DI}_{2} \mathbf{B}$ & 45 & 6 & 7,5 \\
\hline \multirow{18}{*}{ (Pool No. 2) } & $\mathrm{DH}_{2} \mathrm{E}$ & 30 & 3 & 10 \\
\hline & $\mathrm{DH}_{2} \mathrm{~B}($ & 26 & 3 & 8,66 \\
\hline & $\mathrm{DC}_{2} \mathrm{~A}$ & 50 & 10 & 5 \\
\hline & $\mathrm{DE}_{2} \mathrm{~A}$ & 56 & 7 & 8 \\
\hline & $\mathrm{DD}_{2} \mathrm{~B}$ & 60 & 9 & 6,66 \\
\hline & $\mathrm{DG}_{2} \mathrm{~A}$ & 38 & 5 & 7,6 \\
\hline & $\mathbf{D G}_{2} \mathbf{E}$ & 15 & 5 & 3 \\
\hline & $\mathrm{DC}_{2} \mathrm{C}$ & 28 & 3 & 9,33 \\
\hline & $\mathrm{DI}_{2} \mathbf{E}$ & 25 & 5 & 5 \\
\hline & $\mathrm{DD}_{\mathbf{2}} \mathrm{A}$ & 45 & 4 & 11,2 \\
\hline & $\mathbf{D F}_{2} \mathbf{B}$ & 35 & 5 & 7 \\
\hline & $\mathrm{DC}_{2} \mathrm{~B}$ & 35 & 7 & 5 \\
\hline & $\mathrm{DE}_{2} \mathrm{~B}$ & 45 & 18 & 2,5 \\
\hline & $\mathrm{DH}_{2} \mathrm{~B}$ & 28 & 4 & 7 \\
\hline & $\mathrm{DH}_{2} \mathrm{~B}$ & 32 & 5 & 6,4 \\
\hline & $\mathrm{DF}_{2} \mathrm{~A}$ & 54 & 12 & 4,5 \\
\hline & $\mathrm{DH}_{2} \mathrm{C}$ & 17 & 12 & 1,42 \\
\hline & $\mathrm{DG}_{2}$ & 22 & 6 & 3,67 \\
\hline
\end{tabular}


Table.3 Characteristics of DI1A

\begin{tabular}{|c|c|}
\hline CHARACTERISTIC & \multicolumn{2}{|c|}{ RESULTS } \\
\hline Macroscopic observations of colonies \\
\hline colonies & Regular \\
\hline Edge & Regular \\
\hline Elevation & Semi-bombed \\
\hline Surface area & Bright and \\
\hline Color & Whiteish \\
\hline Pigmentation & Green \\
\hline Breathing mode & Aerobics \\
\hline Mobility & Positive \\
\hline Growth at $55^{\circ} \mathrm{C}$ & Positive \\
\hline Microscopic observations & \\
\hline Shape & Stick \\
\hline Formation of & Yes \\
\hline Mobility & Positive \\
\hline Gram staining & Positive \\
\hline Catalase test & Positive \\
\hline Oxydase & Positive \\
\hline
\end{tabular}

Photo.1 Lipolytic strains presenting the halo on Olive oil Rhodamine B Agar medium

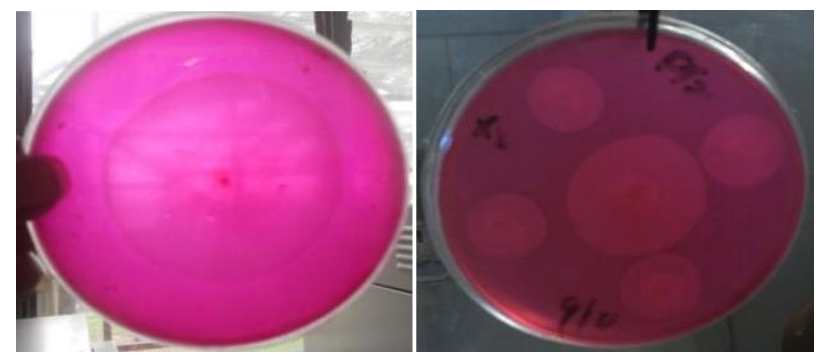

Photo.2 Relative activity of the crude enzyme on Rhodamine B agar medium

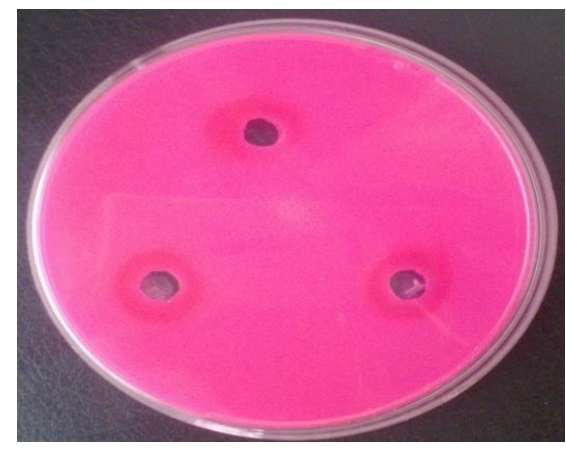


Fig.1 Relative activity of isolates

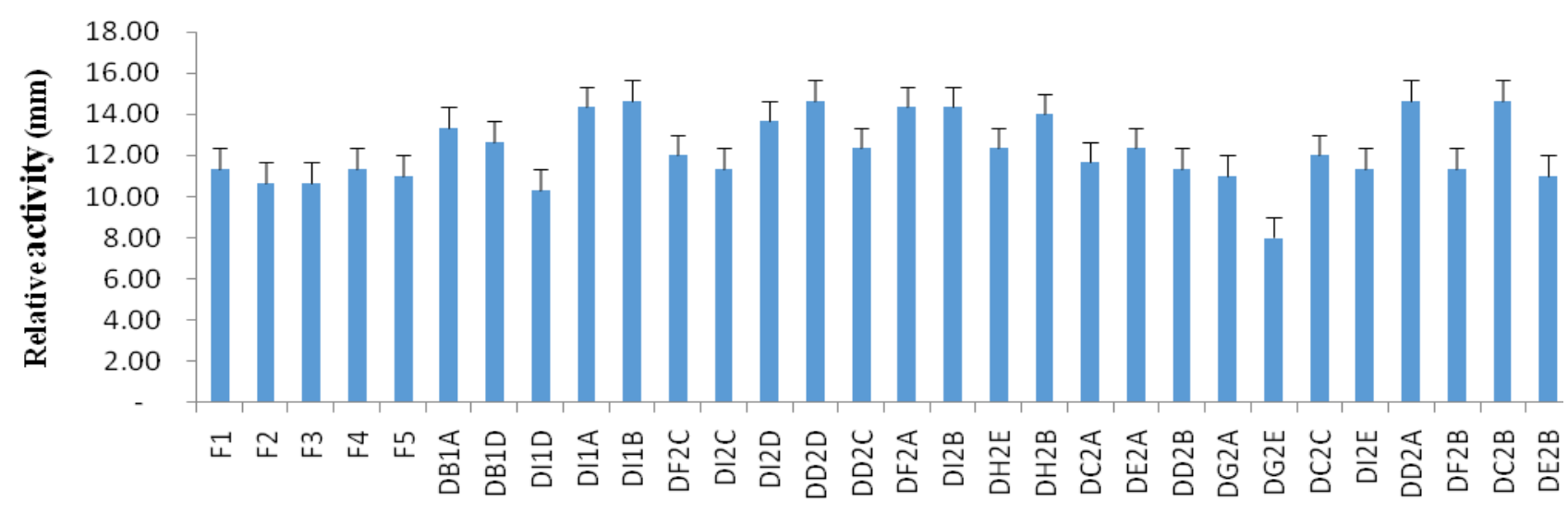

\section{Isolates}

Fig.2 Enzymatic activity of the best pre-selected isolates

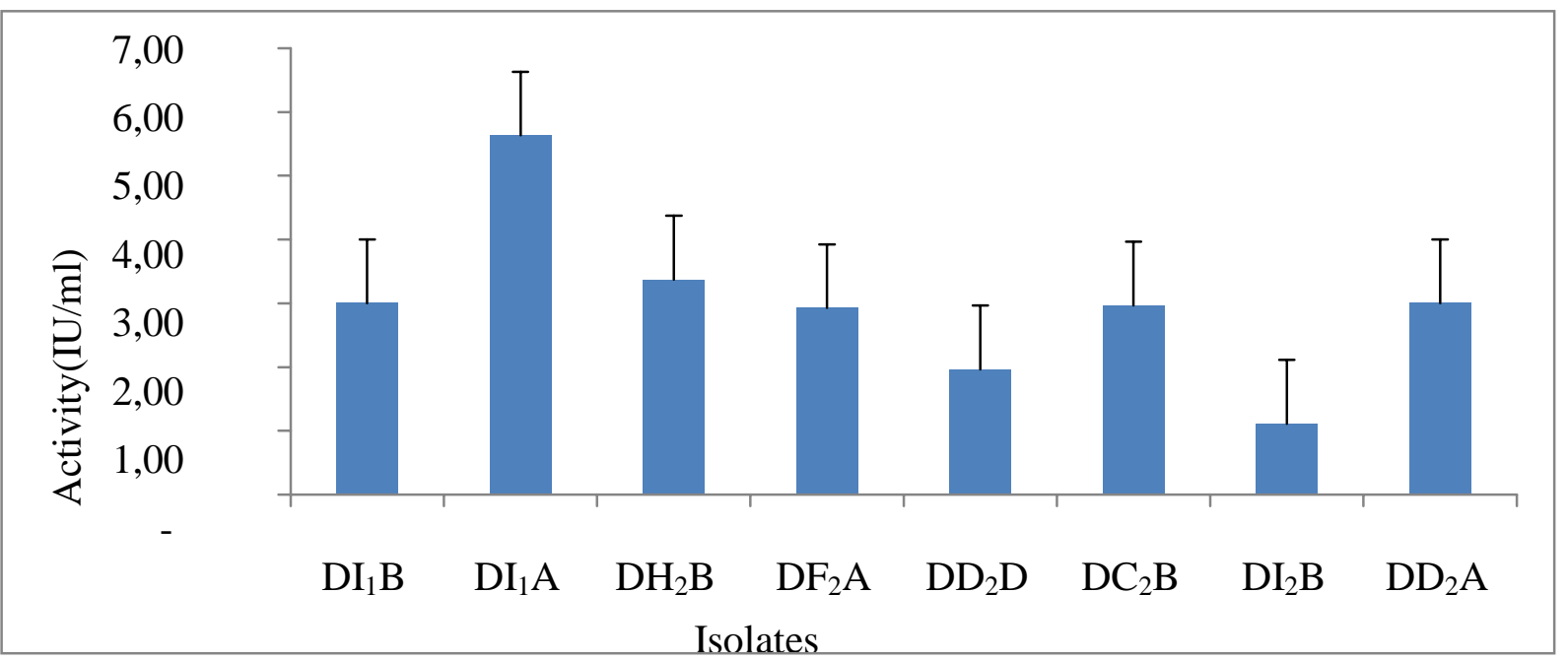

Fig.3 Influence of temperature on enzymatic production

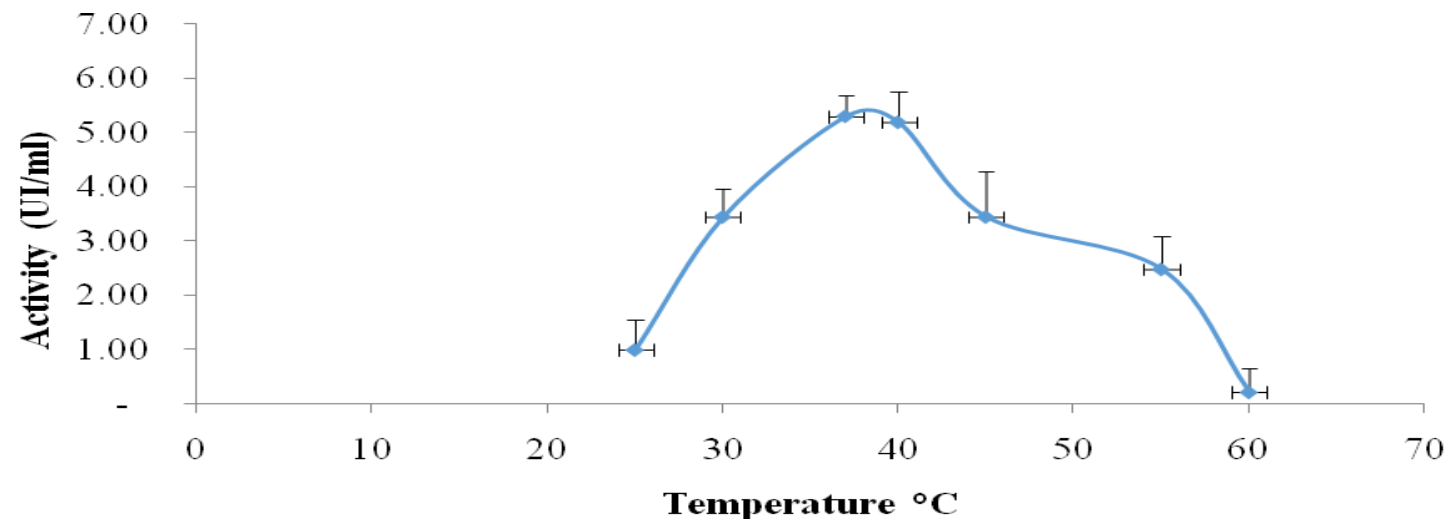


Fig.4 Influence of $\mathrm{pH}$ on enzymatic production

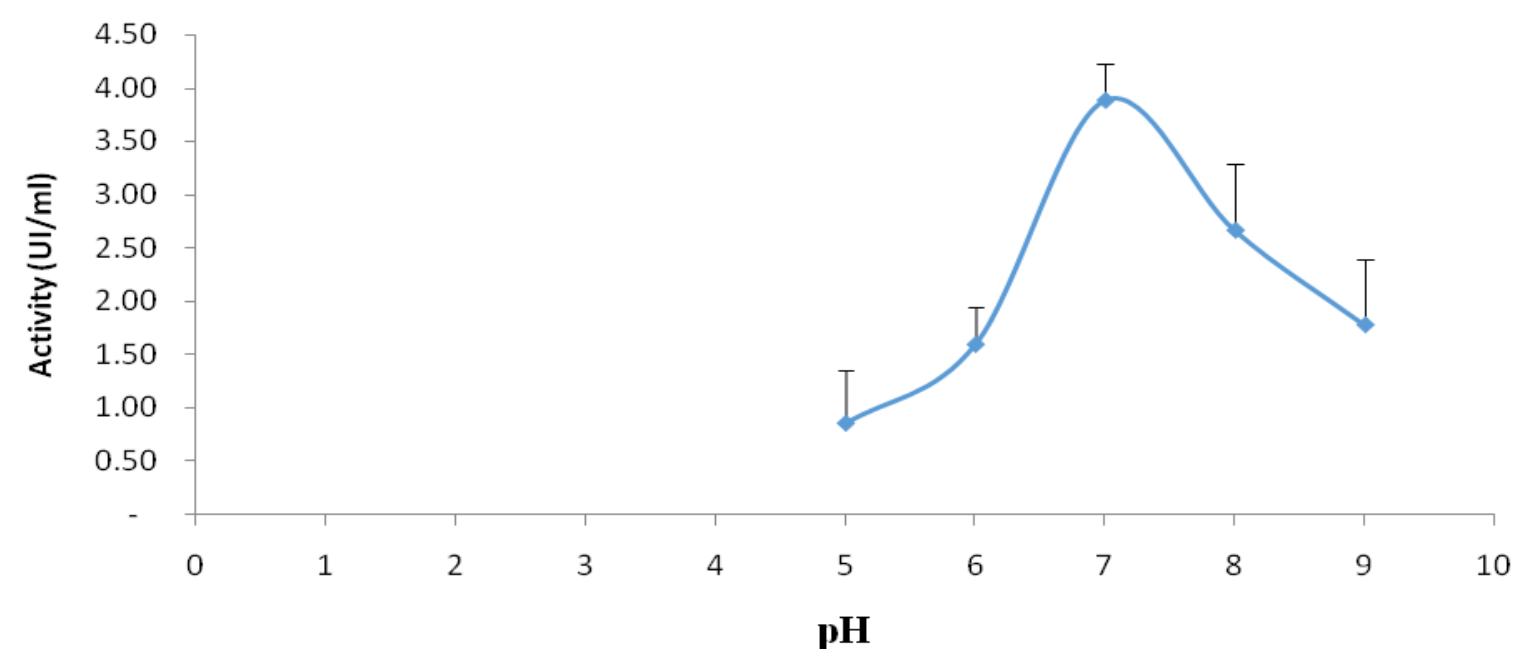

Fig.5 Influence of the shaking speed

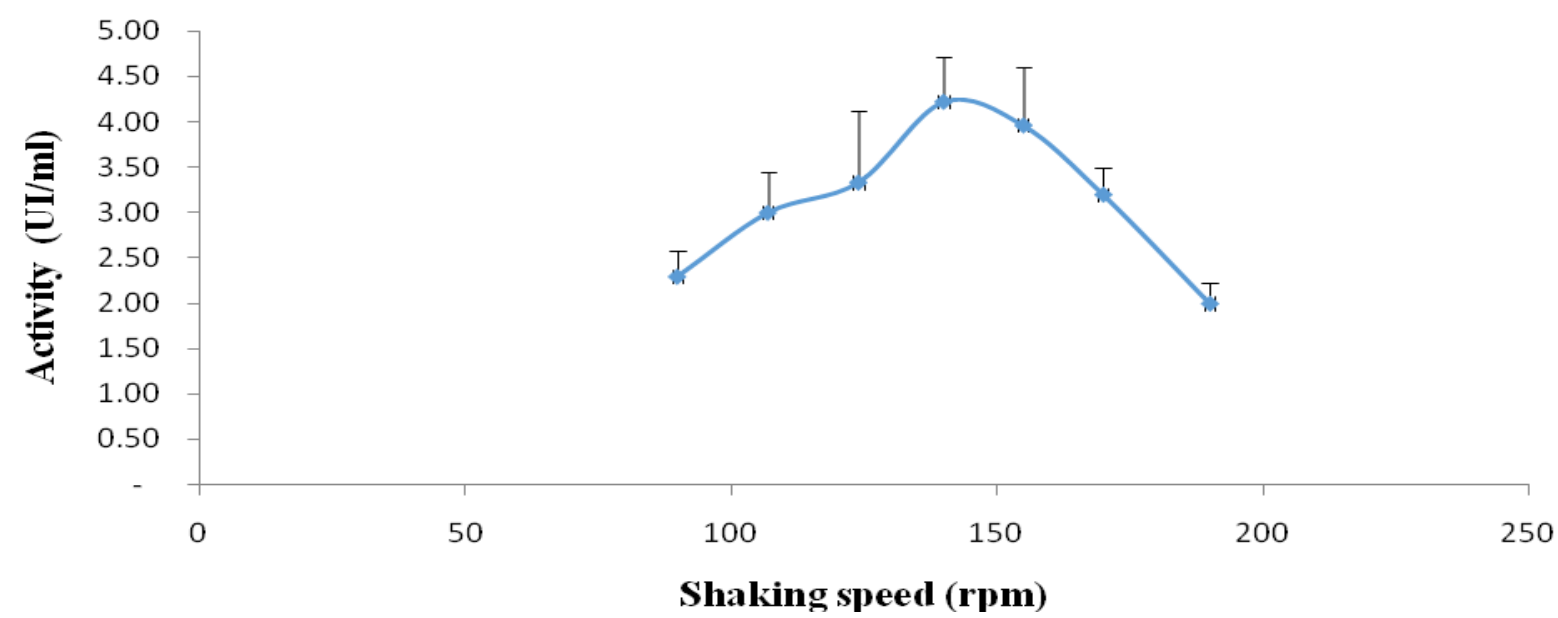

Fig.6 Influence of fermentation time

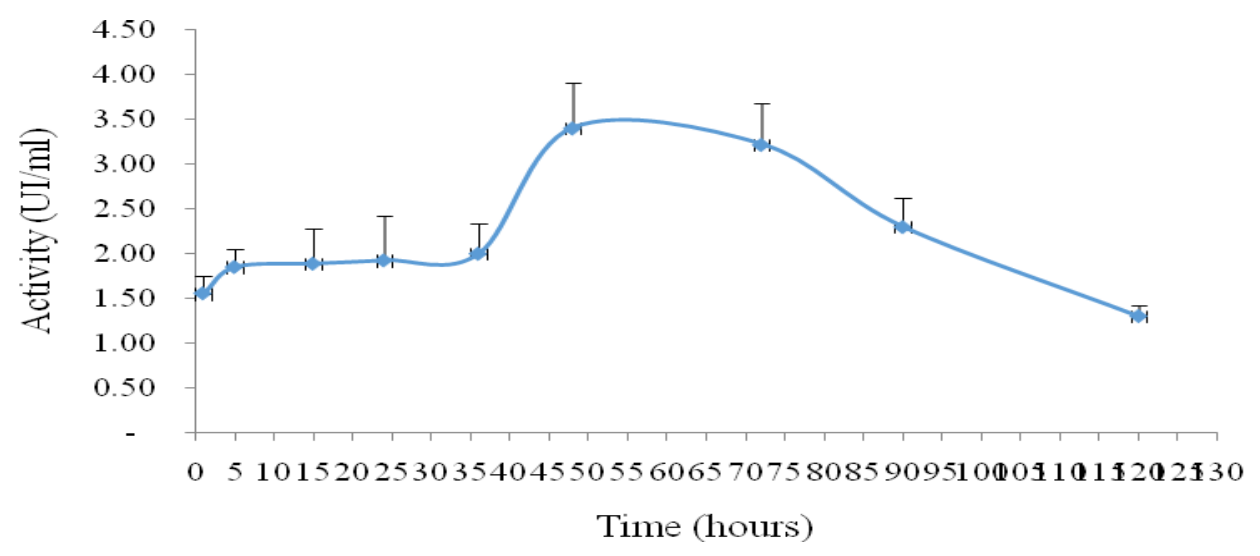


Fig.7 Influence of the carbon source

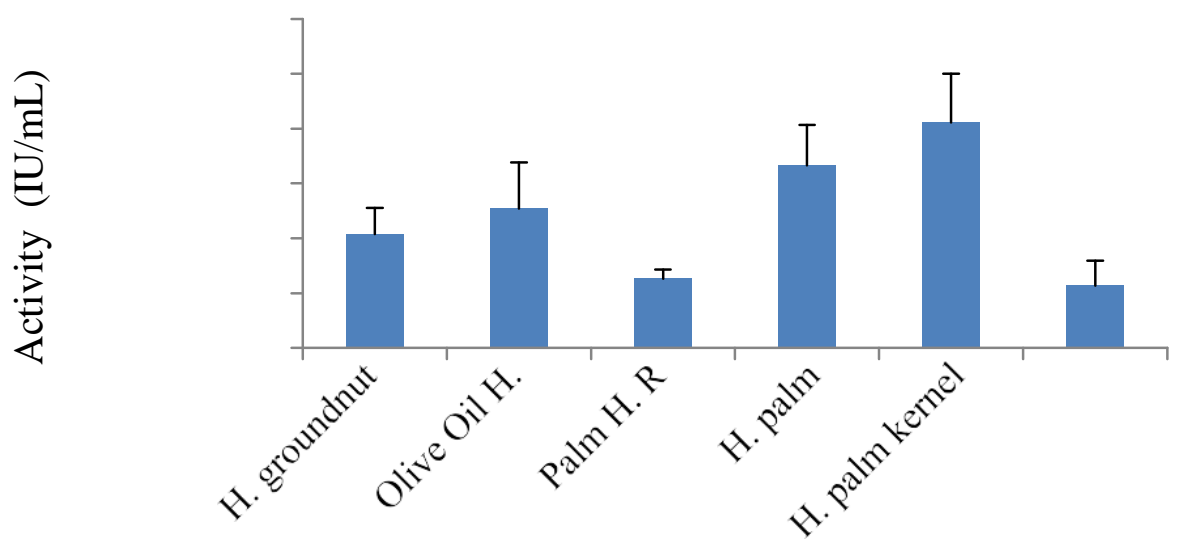

Fig.8 Influence of substrate concentration

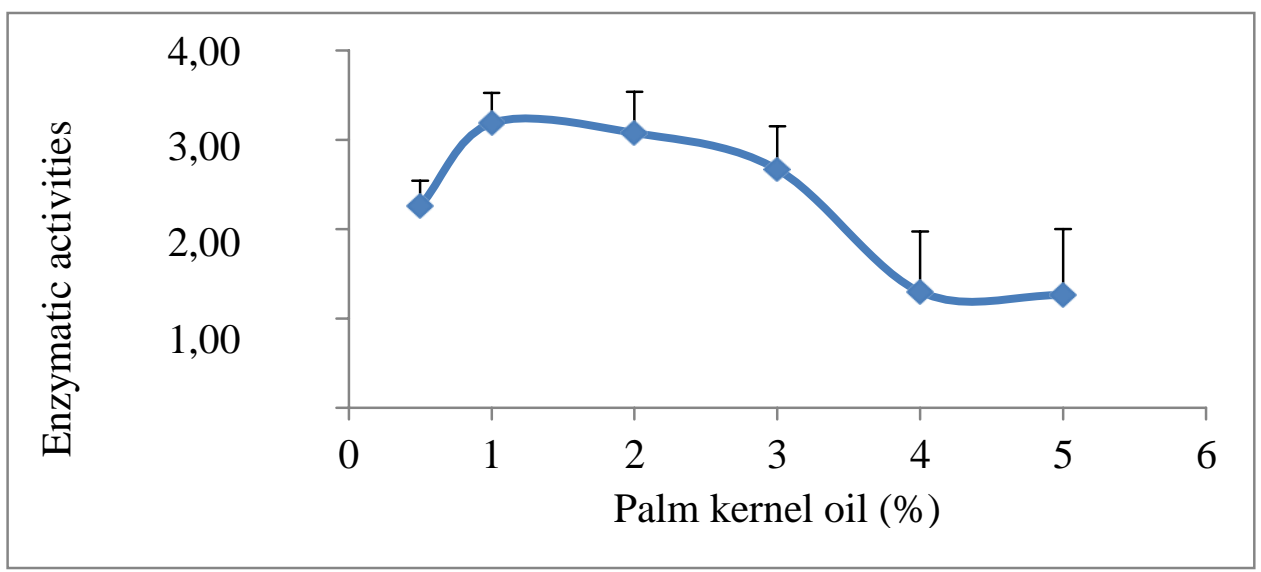

Fig.9 Influence of nitrogen source

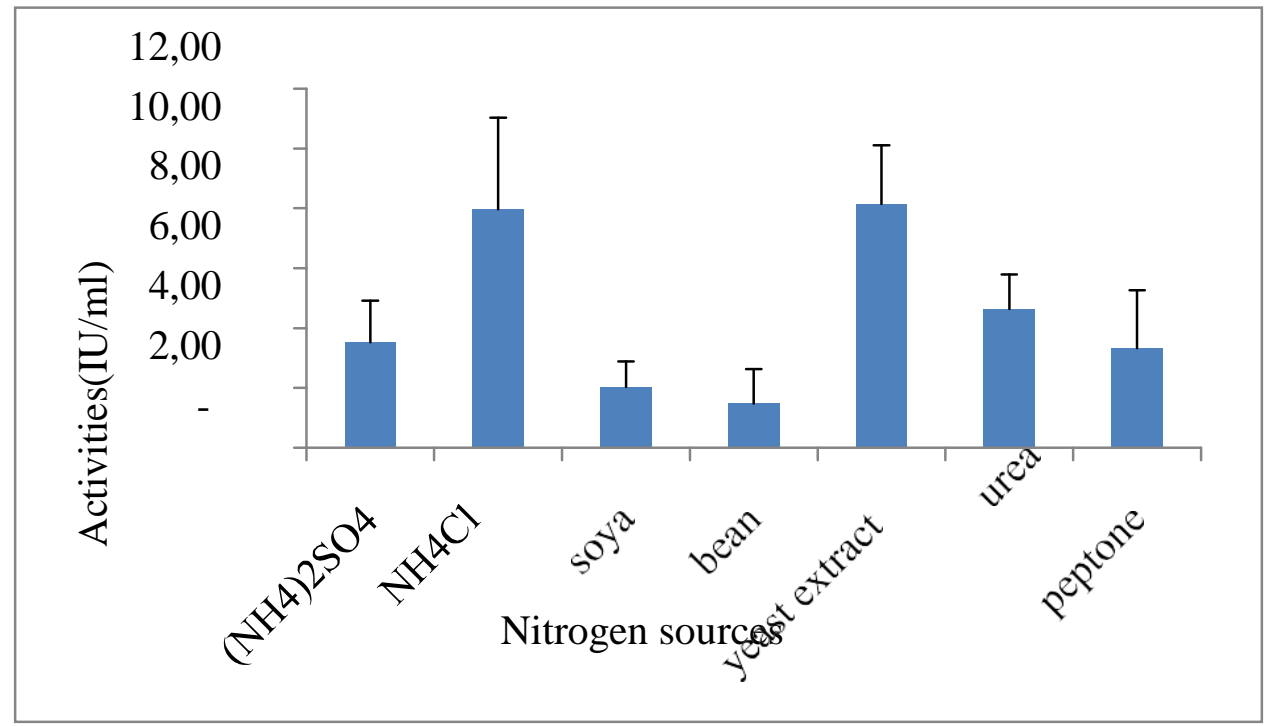


Fig.10 Influence of ammonium chloride concentration (nitrogen source)

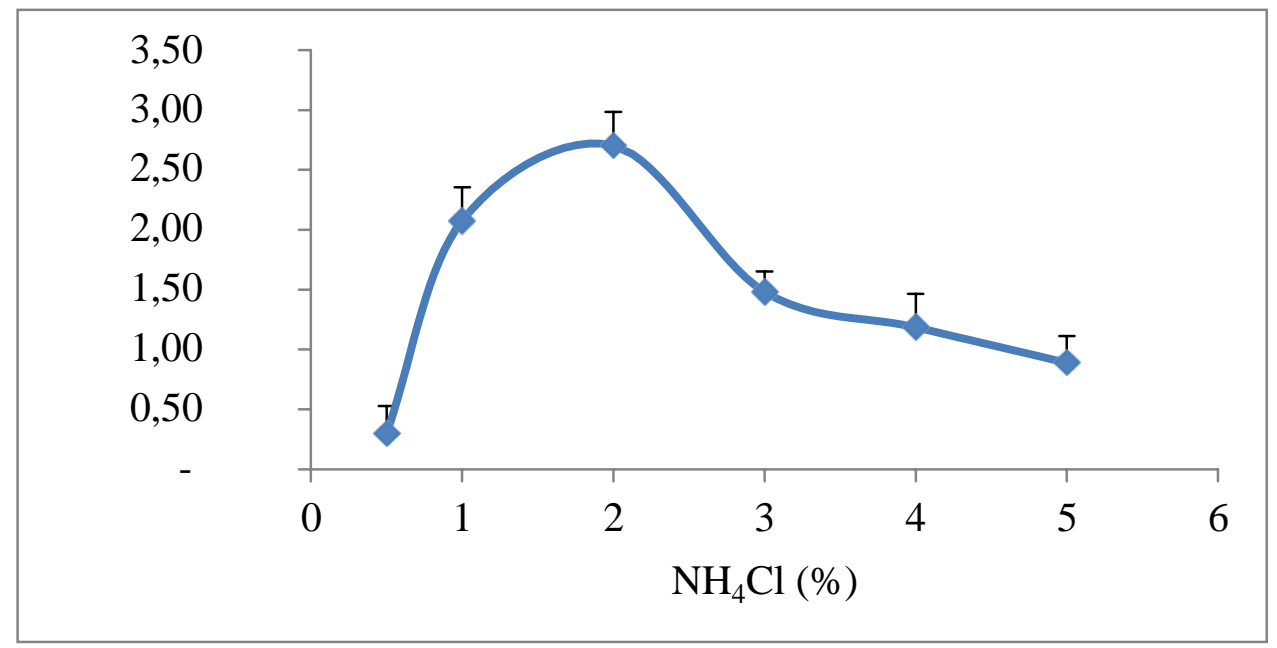

Fig.11 Influence of mineral salts

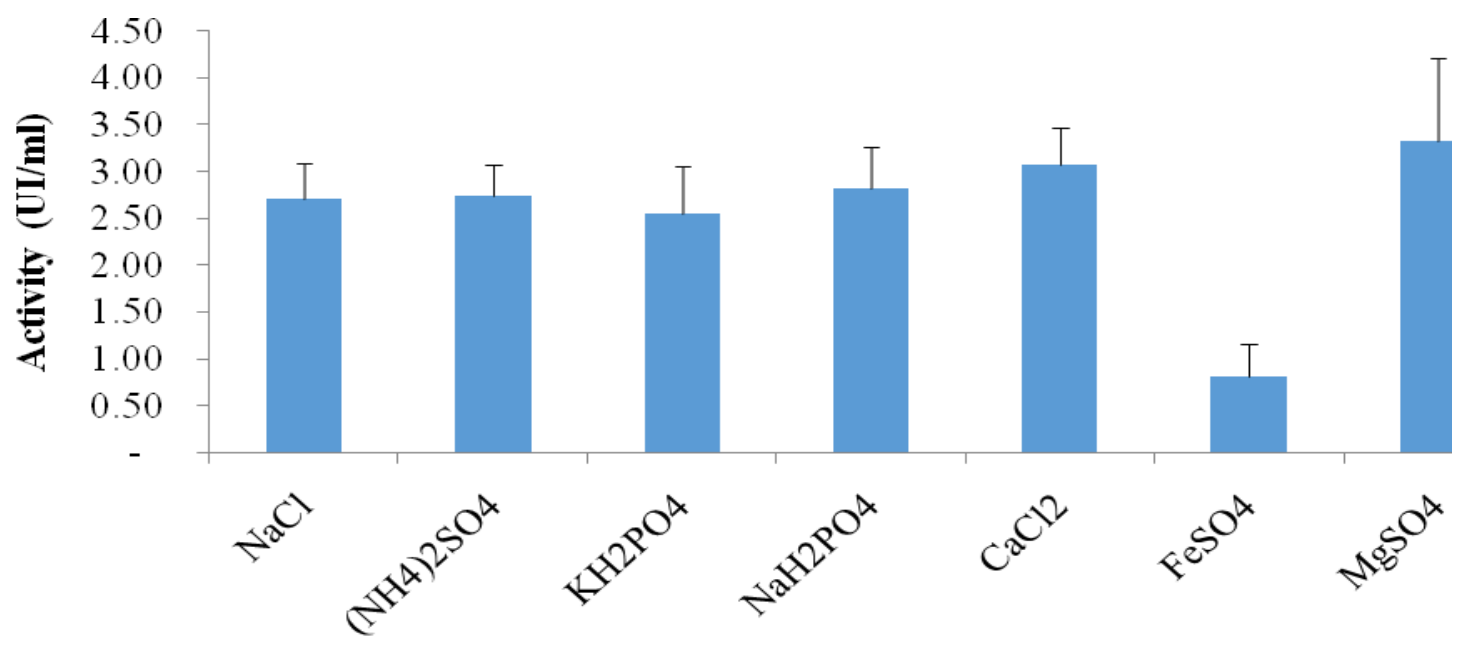

Mineral salts sources

Fig.12 Influence of $\mathrm{MgSO}_{4}$ concentration

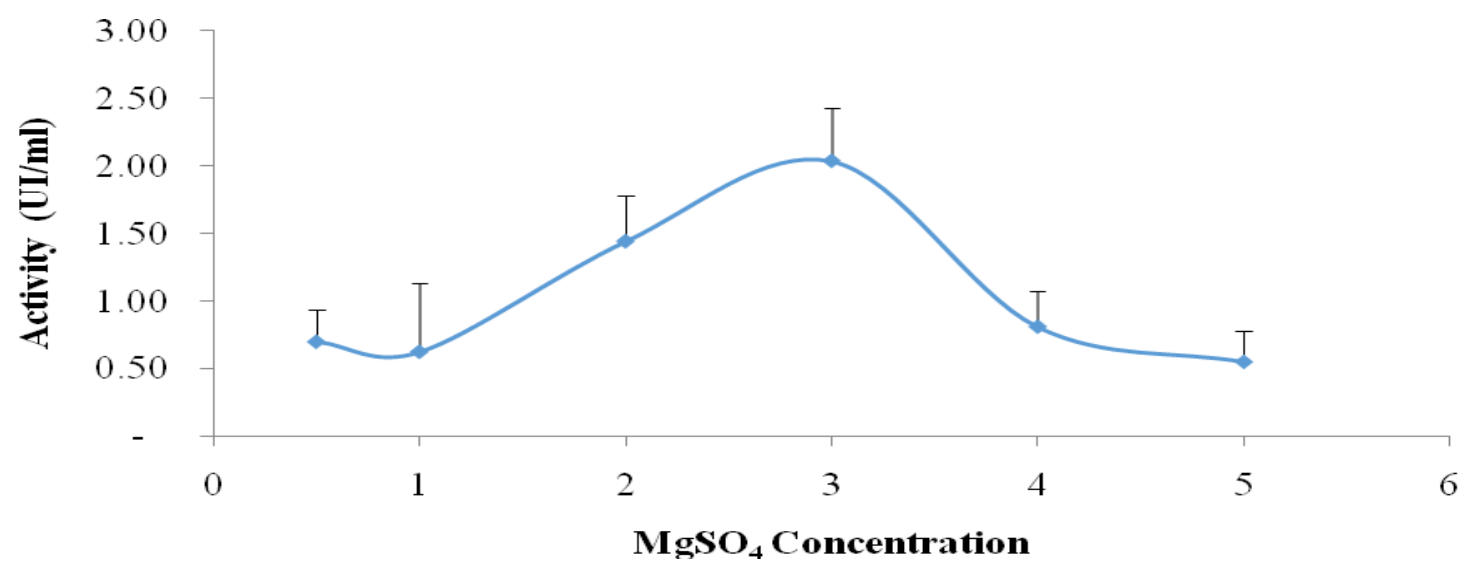


Fig.13 Influence of temperature on enzymatic activity

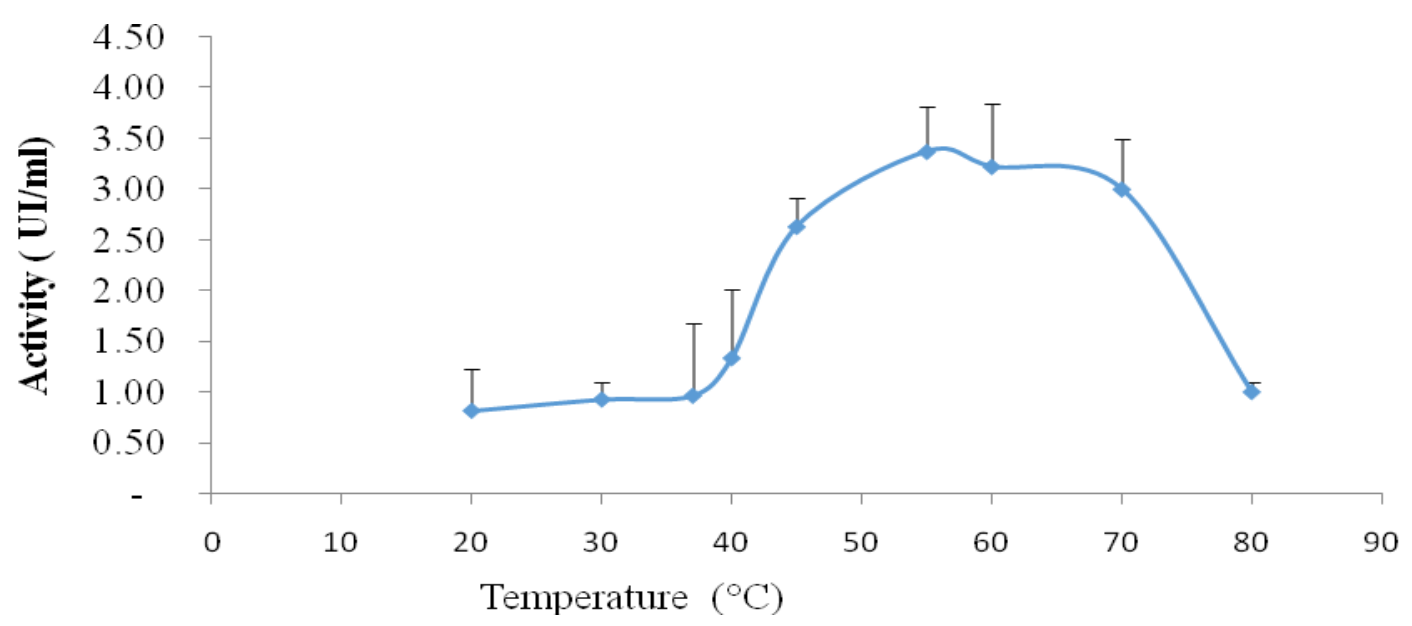

Fig.14 Influence of pH on enzymatic activity

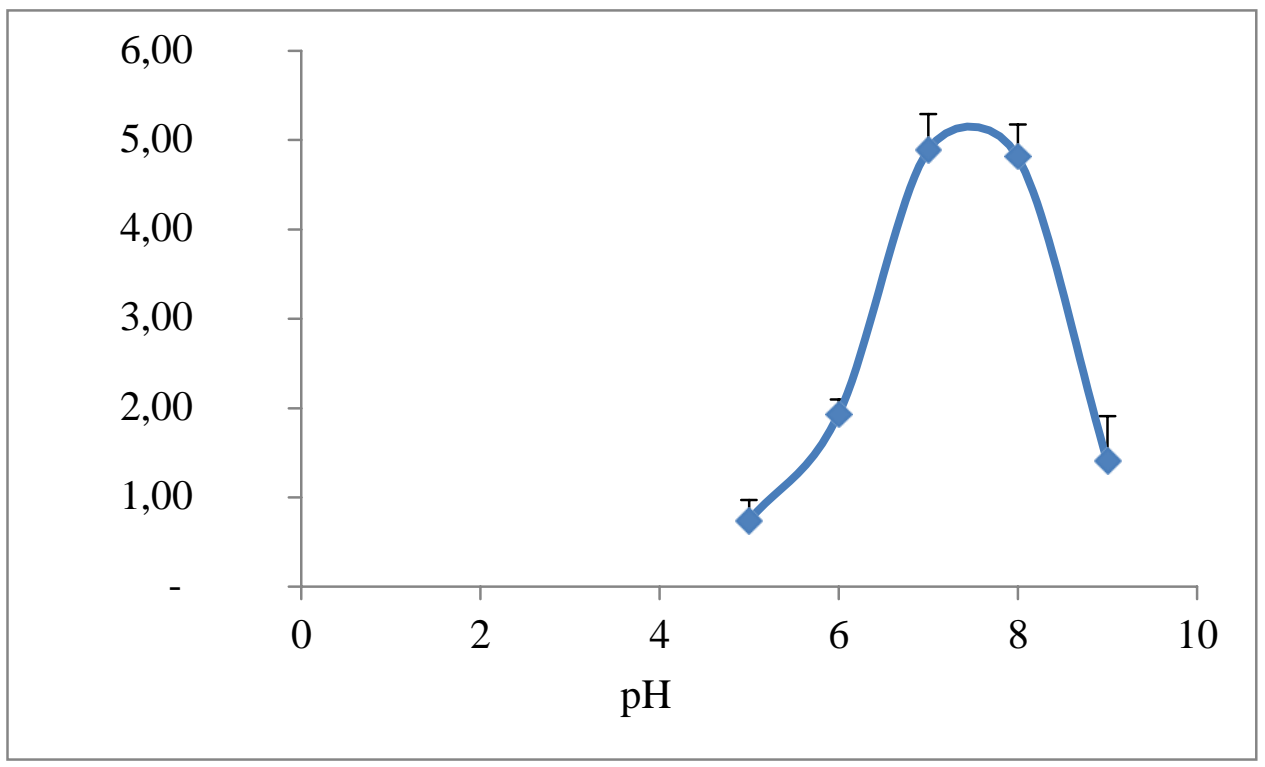

In conclusion, soil samples from palm oil production areas are colonized by bacteria. The latter have high lipolytic capacities. The study of these bacteria shows that this property can be improved by varying the physicochemical parameters. The enzymes produced are of good thermostability and can therefore be used in industry

\section{Acknowledgement}

Special thanks to Bella Jossiane and Kuisseu Yannick Angelin who were of a great assistance in the laboratory during this work. The authors are also thinking about $\mathrm{Mr}$ Hawadak Joseph from the laboratory of molecular and cellular biology and to $\mathrm{Mr}$ Mounbain Francis of the laboratory of natural substances who helped in editing this paper. I am grateful to all of you.

\section{References}

Abdollahi M. and Karbalaei-Heidari H. R. 2014. Isolation, identification, 
biochemical properties and potential application of an organic solventtolerant lipase from Pseudomonas sp. strain NEB-1. Iranian Journal of Science \& Technology.

Bhavani M., Chowdary G. V., David M. and Archana G. 2012. Screening, Isolation and Biochemical Characterization of Novel Lipase Producing Bacteria from Soil Samples. International Journal of Biological Engineering, 2(2): 18-22.

Chibuogwu O. J., Nweke C. O., Nwabueze R. N., Nwanyanwu C. E.; Alisi C. S. and Etim-Osowo N. E. N. 2009. Production and properties of $\alpha$-amylase from Citrobacter species. An Inter disciplinary Journal of Applied Science. 4: 45-57.

Darah I., Sumathi G., Jain K. and Lim S. H. 2011. Influence of agitation speed on tannase production and morphology of Aspergillus niger FETL FT3 in submerged fermentation. Applied Biochemistry and Biotechnology. 165: 1682-1690.

Fergus P. G. 2008. Biotechnology, Biological Fundamentals: Bacillus. 1(2): 367-373.

Gupta R., Gupta N. and Rathi P. 2004.Bacterial lipase: an overview of production, purification and biochemical properties. Applied microbiology and technology. 64(6): 763-781.

Huda J. M. 2013. Physicochemical Factors Affected the Partial Purified Lipase Activity of Acinetobacter baumannii "local isolates" Iraqi Journal of Pharmaceutical Sciences, 22 (1).

Hupé J. F. 2008. (Thesis) Enrichment and research of certain enzymatic activities produced by thermophilic aerobic bacteria. University of Quebec. INRSInstitut Armand-Frappier.

Jaeger K. E. and Reetz M. T. 1998. Microbial lipases from versatile tools for biotechnology. Trends biotechnol. 16:
396-403

Janssen P. H., Monk C. R. and Morgan H. W. 1994. A thermophilic, lipolytic Bacillus $s p$, and continuous assay of its $\mathrm{p}$ nitrophenyl-palmitate esterase activity. FEMS Microbiology Letters. 120: 195200.

Jyoti V. and Avneet K. 2006. Yeast lipases: enzyme purification, biochemical properties and gene cloning. Microbial Biotechnology Electronic Journal of biotechnology 1(9).

Khataminezhad M. R., Nuhi A., Razavi M. R., Nejadsattari T. and Nazemi A. 2014. Isolation and molecular identification of extracellular lipase-producing bacillus species from soil. Scholars Research Library Annals of Biological Research, 5(1):132-139.

Kok R. G., Thor J. J. V., Roodzant I. M. N., Brouwer M. B. W., Egmond M. R., Nudel C. B., Vosman B. and Hellingwer K. J. 1995.Characterization of the extracellular lipase lipA of Acinetobacter colcoaceticus BD413 and sequence analysis of the cloned structural gene. Mol. Microbiol. 15: 803.

Kulkarni N.et Gadre R.V. 1999. A novel alkaline, thermostable, protease-free lipase from Pseudomonas sp. Biotechnology Letters. 21(10): 897-899.

Leonov S. L. (2010). Screening for novel cold-active lipases fromwild type bacteria isolates Innovative. Romanian Food Biotechnology, Vol. 6.

Meenakshi N. and Hindumathy C. K. 2012. Isolation, optimization and purification of lipase from Myroides odoratimimus. International Journal of Latest Research in Science and Technology. 1(3): 239-246.

PatilK. J., Chopda M. Z. and Mahajan R. T. 2011. Lipase Biodiversity (A review); Indian Journal of science and technology. 4(8): 971-982. 
Pokorny D., Friedrich J. and Cimerman A. 1994. Effect of nutritional factors on lipase biosynthesis by Aspergillus niger. Biotechnol. Lett. 16:363-6.

Qing., Xu W., Meng S., Jinjin H., Guohua G., Ying L. and Bo S. 2014. Isolation of a novel alkaline-stable lipase from a metagenomic library and its specific application for milk fat flavor production. Pengetal Microbial Cell Factories, 13: 1.

Savitha J., Srividya S., Jagat R., Payal P., Priyanki S., Rashmi G. W., Roshini K. T. and Shantala Y. M. 2007. Identification of potential fungal strain(s) for the production of inducible, extracellular and alkalophilic lipase. African Journal of Biotechnology 6(5): 564-568.

Seeley W. H. and Vandemar k P. J. 1981. Microbes in action: A laboratory manual of microbiology. 3:35-36

Shakila M. Begam, Stanly F. Pradeepet Pradeep B. V. 2012. Production, purification, characterization and applications of lipase from Serratia marcescens mbb05. Asian Journal of Pharmaceutical and Clinical Research. 5(4): 1974-2441.

Sharma R., Chisti Y. and Banerjee U. C. 2001. Production, purification, characterization, application of lipases. Biotechnology advances. 19:627-662.
Sharma S., Ashish S. and Baplu R. 2012. (Project report) Screening, optimization and pilot scale production of enzyme Lipase in a bioreactor from Aspergillus species.

Sharon C., Furugoh S., Yamakido T., Ogawa H. and Kato Y. 1998. Purification and characterization of a lipase from Pseudomonas aeruginosa KKA-5 and its role in castor oil hydrolysis. J. Ind Microbiol Biotechnol. 20:304-7.

Sourav B., Shilpi B., Arijit D. and Sanchita A. 2011. Utilization of sugarcane bagasse for solid- state fermentation and characterization of $\alpha$ - amylase from Aspergillus flavus isolated from Muthupettai Mangrove, Tamil Nadu, India. Australian Journal of Basic and Applied Sciences. 5:1012-1022.

USDA/FAS 2011. National Nutrient Database.

Veerapagu M., Sankara Narayanan A., Ponmurugan K. and Jeya K. R. 2013.Screening selection identification production and optimization of bacterial lipase from oilspilled soil. 6(13).

Wilke D. 1999. Chemicals from biotechnology: molecular plant genetics will challenge the chemical and the fermentation industry (mini-review). Applied Microbiology and Biotechnology. 52(2): 135-145.

\section{How to cite this article:}

Fobasso Tagnikeu Romeo, Tavea Fréderic Marie, Tetso Ghislain Brice, Tchamba Mbiada Mervie Noel, Tcheugoue Styve Joel, Momo Gautier and Etoa François Xavier. 2019. Screening and Isolation of Lipase Producing Bacteria from Contaminated Soils from the Littoral-Region of Cameroon and Partial Study of the Fermentation Conditions of the Crude Enzyme Produced. Int.J.Curr.Microbiol.App.Sci. 8(05): 296-312. doi: https://doi.org/10.20546/ijcmas.2019.805.035 